\title{
Comparison the Self-Esteem among Different Designated Teachers of Undergraduate College
}

\author{
Dipankar Das ${ }^{1 *}$, Md. Kutubuddin Halder ${ }^{2}$ \\ ${ }^{1}$ Ph.D. Scholar, Department of Education, University of Calcutta, Kolkata, West Bengal, India \\ ${ }^{2}$ Professor, Department of Education, University of Calcutta, Kolkata, West Bengal, India
}

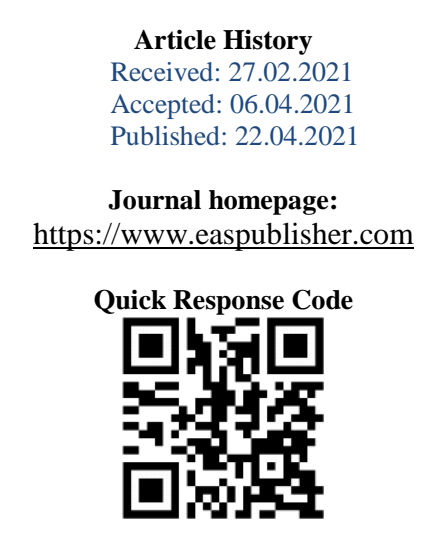

\begin{abstract}
College teachers are the pivot of an educational system. Self-esteem of teachers affects their personal, professional as well as social development, happiness, satisfaction and adjustment. The present study focuses to compare the self-esteem among the three categories of Undergraduate college teachers. Therefore, the present study was designed to find out the self-esteem level of designation-wise college teachers and to find out the difference of self-esteem among designation-wise undergraduate college teachers. For this purpose, total 270 Undergraduate (Associate Professors=90, Assistant Professors= 90 and Part-time $\&$ Guest teachers $=90$ ) College teachers were used. Descriptive survey design was used in this study. The data was collected through Random sampling technique and using by Self-esteem scale [1]. Mean, SD, Percentage, ANOVA \& t-test were used for analysis the data. The study observed that $51.11 \%$ of Associate Professor, $33.33 \%$ Assistant Professor and $15.56 \%$ part-timer and guest faculty are extremely high Self-esteem. 47.78\% Associate Professor, 64.45\% Assistant Professor and $70 \%$ Part-timer and guest are normal self-esteem. While $1.11 \%$ Associate professor $2.22 \%$ Assistant Professor and $14.44 \%$ part-timer and guest are low selfesteem. The present study found that there is a significant difference in regard to self-esteem score among designation-wise (Associate Professor, Assistant Professor and Part-time and guest faculty) Undergraduate college teachers. The present showed that there is a significant difference in regard to self-esteem score between Associate and Assistant Professors of Undergraduate college. The research found that there is a significant difference in regard to self-esteem score between Associate Professors and Part-time \& Guest teachers of Undergraduate college. The study also found that there is a significant difference in regard to selfesteem score between Assistant Professors and Part-time \& Guest teachers of Undergraduate college.

Keywords: Self-esteem, Undergraduate College teachers, West Bengal, India.
\end{abstract}

Copyright (C) 2021 The Author(s): This is an open-access article distributed under the terms of the Creative Commons Attribution 4.0 International License (CC BY-NC 4.0) which permits unrestricted use, distribution, and reproduction in any medium for non-commercial use provided the original author and source are credited.

\section{INTRODUCTION}

The concept of self-esteem is initiated by William James in 1890. According to James [2], selfesteem is a product of perceived competence in domains of important aspect of mental health. This means self-esteem is derived from thinking. We are good at things that have significance to us, but not those we don't personally value. In this sense, Rosenberg [3], stated that the basic concept of self-esteem is that each individual has an internal worth and has internalized certain values. These internal values make the people feel that they are significant as human beings and everyone regularly aspires to improve that worth. It is an individual's overall evaluation of one's self-worth or self-image. According to Maslow's need hierarchy theory of motivation, the esteem needs have two versions, a lower one and a higher one. The lower one is the need for the respect of others, the need for status, fame, glory, recognition, attention, reputation, appreciation, dignity, even dominance. The higher form involves the need for self-respect, including such feelings as confidence, competence, achievement, mastery, independence, and freedom. According to Blascovch \& Tomake [4] define self-esteem as generally as an evaluative component of the self- 
concept, a broader representation that includes cognitive and behavioural aspects as well as evaluative or affective ones. Besides, Garry [5], defined that Selfesteem is focused upon feeling of personal worth's and the level of satisfaction regarding one's self.

Workplace self-esteem of an individual specifies his/her professional position and acceptance in that professional role in respect of his or her personal self-regards. Besides, Payne [6], defined that workplace self-esteem can be defined as the feelings of worth or value employees feel within their workplace. It also means the extent to which employees believe that they can satisfy their needs by participating in roles within the workplace [7]. According to Chan et al., [8] workplace self-esteem reflects employee's selfperception about importance, meaningfulness, effectiveness, competence, and worthiness within their workplace. Employees with high self-esteem, who feel as meaningful, effectual and worthwhile in the workplace which they work for [9]. Besides, Diener and Diener [10] showed that high Self-esteem has been regarded as one of the basic requirements of personal well-being, happiness and adjustment. On the other hand, Sahu, S et al., [11], revealed that individuals with higher self-esteem are more satisfied with their lives, less interpersonal problems, achieves more, lower psychological problems like anxiety, depression, etc. and physical illness than those with lower self-esteem.

\section{Operational Definitions \\ Self-Esteem}

In this study, the term self-esteem is used to describe teacher's professional position, acceptance, competency, and fulfilment of professional demands and expectations in his or her job.

College Teachers: In this study, College teachers refers to under graduate (B. A/B.Sc./B. Com) Degree College teachers affiliated to University of Calcutta, West Bengal. Here researcher has included three categories of college teachers' i.e.

- Associate Professor

- Assistant Professor

- Part-time \& Guest lecturer

\section{REVIEW OF LITERATURE}

Jan, F et al., [12] revealed that the self-esteem is a continuous personal evaluation of his/her selfvalidness and feeling of self-esteem is created due to the need for positive attention and the need for others positive attention includes feedback, warm and lovely behaviour, respect, intimacy, acceptance and kindness from the environment especially the teachers. Tabassum, F., \& Ali, A. M. [13] showed that there was no significant difference in the level of professional self-esteem of arts and science teachers. The research also found that there was a significant difference in the level of professional self-esteem of overall male and female teachers. They also showed that there was no significant difference in the level of professional selfesteem of rural and urban secondary school teachers. Vigeneshvaran $\mathrm{K}$ et al., [14] revealed that female teachers have more self-esteem than male teachers. On the other hand, they showed that teachers who teach science subject are having less self-esteem than the teachers who teach arts subjects. Shah, K., \& Pathak, S [15] revealed that there was no significant difference between secondary and higher secondary school teachers on self-esteem. This study also found that there is no significant difference between male and female school teachers in relation to self-esteem. On the other hand, they also showed that there was no significant difference between secondary and higher secondary school teachers experience more than 10 years and less than 10 years' experience on self-esteem. Dey, K. B et al., [16] indicated that positive correlation between job satisfaction and self-esteem of the teachers. Zafar, $\mathrm{N}$ et al., [17] revealed that self-esteem and job satisfaction were not affected by gender or type of school. Cevik, B. $G$ [18] found that satisfactions with life, teacher efficacy and self-esteem had important role in teachers job satisfaction. This study also found that teachers with high self-esteem were found to have high job satisfaction. They also concluded that low level of selfesteem may lead to experiences of dissatisfaction in profession for the teachers.

\section{Objectives of the study}

- To find out Self-esteem level of designation-wise college teachers.

- To find out the difference of Self-esteem among designation-wise college teachers.

\section{Hypotheses:}

- $\quad \mathbf{H}_{\mathbf{0}}$ : There is no significance difference with regard to Self-esteem score among designation-wise (Associate Professor, Assistant Professor and Parttime \& Guest teacher) college teachers.

\section{Methodology of The Study}

Population: The target population for the study are the undergraduate college teachers, affiliated to University of Calcutta, West Bengal, India.

Sample \& Sampling Technique: Random sampling technique was used to data collection for this study. Total sample to be taken for the study was 270 undergraduate college teachers from various colleges of affiliated to University of Calcutta. The sample has been stratified in terms of designation wise (Associate Professor, Assistant Professor and Part-time \& Guest teachers) The description of the sample design is given below, in the Table- 1 . 
Table-1: Sample design of college teachers

\begin{tabular}{|l|l|l|l|}
\hline Associate Professor & Assistant Professor & Part-time \& Guest & Total \\
\hline 90 & 90 & 90 & 270 \\
\hline
\end{tabular}

Research design: The descriptive survey research design was used in this research.

Research Tools: The following research tools was used for this study.

Personal Information Sheet: The personal data sheet developed by investigator was used to collect information about their name, gender, age, educational qualification, designation.

Self-esteem Scale: This scale was developed by Dr. Santosh Dhar and Dr. Upinder Dhar [1]. It has 23 items. This scale has six factors like positivity, openness, Competence, Humility, Self-worth, and Learning orientation. It is a five-point Likert type scale namely Strongly Agree, Agree, Neutral, Disagree, and Strongly disagree. The reliability of this scale is 0.87 , which was calculated on the basis of split half method.

\section{Variables of the study}

Independent Variables: Designation of college teachers (Associate Professor, Assistant Professor and Part-time \& Guest Teacher).
Dependent Variable: Self-esteem score.

\section{Procedure}

The sample was collected from randomly selected various Undergraduate colleges affiliated to University of Calcutta at Kolkata, Howrah, Hooghly in West Bengal. The permission was taken from the Principals or TIC of randomly selected colleges. A briefing about nature and purpose of the study was given to the participant to develop the rapport. The researcher was assured that all information taken from the participants will be kept confidential. After establishing rapport, Personal information sheet and Self-esteem Scale was administered to all the participants to determine their self-esteem level.

\section{Statistical Techniques}

The SPSS version 21 was used for statistical analysis like Descriptive statistics (mean, standard deviation, percentage) as well as inferential statistics (ANOVA) to the data.

\section{RESUlt AND DiscuSSION Self-esteem level of Teachers}

Table-2: Showing level of Self-esteem of designation-wise College Teachers

\begin{tabular}{|c|c|c|c|c|c|c|c|c|c|}
\hline \multirow[t]{3}{*}{ Sl. No } & \multirow[t]{3}{*}{ Self-esteem Level } & \multicolumn{6}{|c|}{ Designation of the teacher } & \multirow{2}{*}{\multicolumn{2}{|c|}{ Total }} \\
\hline & & \multicolumn{2}{|c|}{ Associate Professor } & \multicolumn{2}{|c|}{ Assistant Professor } & \multicolumn{2}{|c|}{ Part-time \& Guest } & & \\
\hline & & No & $\%$ & No & $\%$ & No & $\%$ & No & $\%$ \\
\hline 1 & High (98 \& more) & 46 & 51.11 & 30 & 33.33 & 14 & 15.56 & 90 & 33.33 \\
\hline 2 & Normal (81-97) & 43 & 47.78 & 58 & 64.45 & 63 & 70 & 164 & 60.74 \\
\hline 3 & Low ( 80 \& below) & 1 & 1.11 & 2 & 2.22 & 13 & 14.44 & 16 & 5.93 \\
\hline \multicolumn{2}{|l|}{ Total } & 90 & 100 & 90 & 100 & 90 & 100 & 270 & 100 \\
\hline
\end{tabular}

Self-esteem level of college teacher of Associate Professor, Assistant Professor and Part-timer and guest faculty is shown in the above table. It is observed that $51.11 \%$ of Associate Professor, 33.33\% Assistant Professor and $15.56 \%$ part-timer and guest faculty are extremely high Self-esteem. $47.78 \%$
Associate Prof., $64.45 \%$ Assistant Prof. and 70\% Parttimer and guest are normal self-esteem. While $1.11 \%$ Associate prof, $2.22 \%$ Assistant Prof. and 14.44\% parttimer and guest are low self-esteem. The result shown in following line graph.

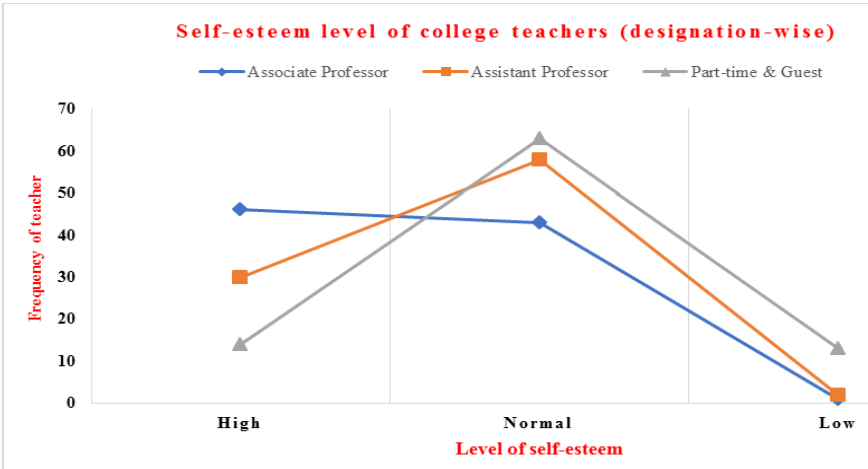

Fig-1: Line Graph on Self-esteem level of College teachers (Designation-wise) 
$\mathrm{H}_{0}$ : There is no difference with regard to Self-esteem score among designation-wise (Associate Professor, Assistant Professor and Part-time \& Guest) college teachers.

Table-3: Showing descriptive statistics of Self-esteem among college teachers

\begin{tabular}{|l|l|l|l|l|}
\hline Designation of College teachers & N & Mean & Std. Deviation & Std. Error \\
\hline Associate Professor & 90 & 97.49 & 8.235 & 0.868 \\
\hline Assistant Professor & 90 & 94.34 & 6.717 & 0.708 \\
\hline Part-time \& Guest teachers & 90 & 88.26 & 8.470 & 0.892 \\
\hline Self-esteem Score & 270 & 93.36 & 8.709 & 0.530 \\
\hline
\end{tabular}

Table-4: Showing One-way ANOVA of Self-esteem among designation-wise college teachers

\begin{tabular}{|l|l|l|l|l|l|l|}
\hline ANOVA & & Sum of Squares & df & Mean Square & F & Sig. \\
\hline \multirow{3}{*}{$\begin{array}{l}\text { Self-esteem } \\
\text { Score }\end{array}$} & Between Groups & 3966.496 & 2 & 1983.248 & & \\
& Within Groups & 16437.933 & 267 & 61.565 & \multirow{3}{*}{32.214} & $.000(*)$ \\
\cline { 2 - 5 } & Total & 20404.430 & 269 & & & \\
\hline
\end{tabular}

There is no significant difference with regard to self- esteem score between Assistant Professor, Associate Professor, Part-time \& guest lecturer of college is rejected at 0.05 level of significance as Fvalue (32.214) is greater than critical value (3.04).
Therefore, it can be said that there is a significant difference with regard to Self-esteem score $\left(\mathrm{F}_{\mathrm{obs}}=\right.$ $32.214>\mathrm{F}_{0.05}, 2,267=3.04$ ) among designation-wise (Associate Professor, Assistant Professor and Part-time and guest) college of teachers.

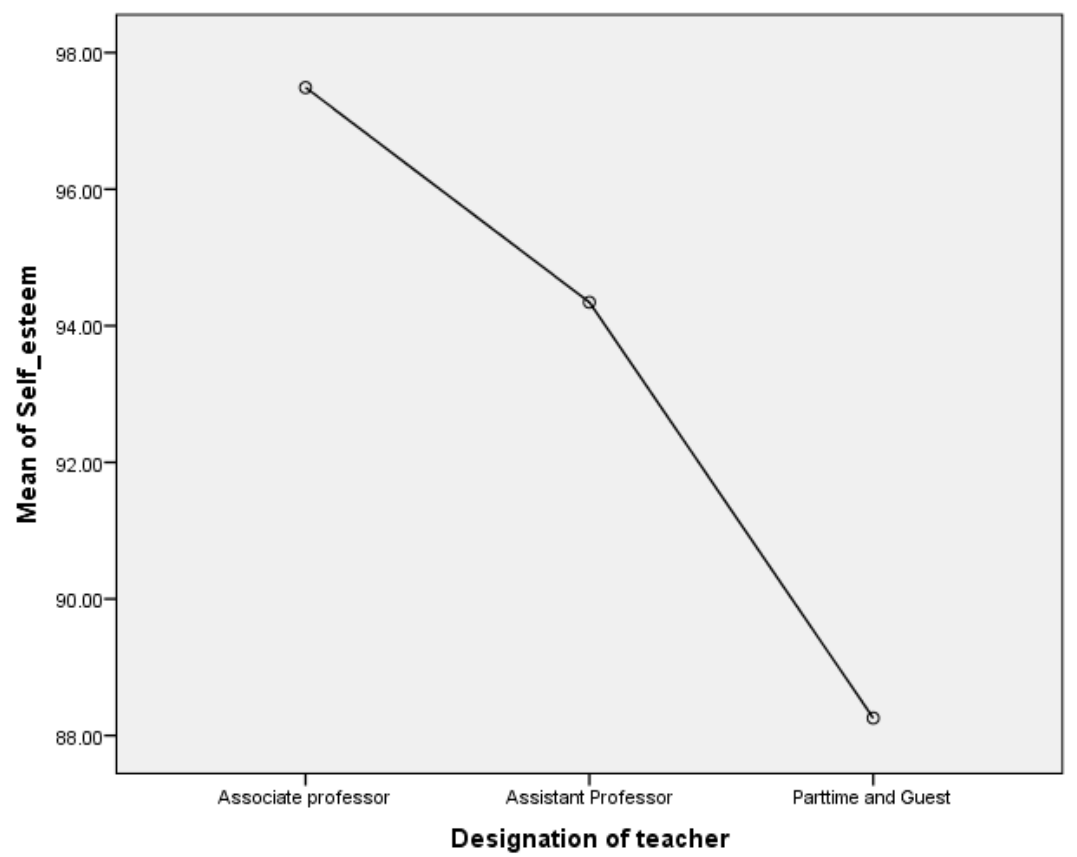

Fig-2: Showing Means plot of self-esteem score among designation-wise college teachers

The mean plot (above) of designation-wise college teachers shows self-esteem score of Associate Professor, Assistant Professor and Part-time \& Guest teachers of college.

So, it is further hypothesized below to find out which group differs from another group.

$>\mathrm{H}_{0}$-a: There is no significant difference with regard to self-esteem score between Associate and Assistant Professor of college.

$>\mathrm{H}_{0}$-b: There is no significant difference with regard to self-esteem score between Associate Professor and part-time \& Guest faculty of college.

$>\mathrm{H}_{0}$-c: There is no significant difference with regard to self-esteem score between Assistant Professor and part-time \& Guest faculty of college.

$\mathrm{H}_{0}$-a: There is no significant difference with regard to self-esteem score between Associate and Assistant Professor of college.

$\mathrm{H}_{0}$-a is tested by employing ' $\mathrm{t}$ ' test. The result is presented in below table. 
Table-5: Showing t-test of Self-esteem between Associate Professors and Assistant Professor of college

\begin{tabular}{|c|c|c|c|c|c|c|c|c|c|}
\hline \multirow[t]{3}{*}{$\begin{array}{l}\text { Self-esteem } \\
\text { Score }\end{array}$} & $\begin{array}{l}\text { Designation of } \\
\text { teachers }\end{array}$ & $\mathbf{N}$ & Df & Mean & SD & $\begin{array}{l}\text { Std. error } \\
\text { mean }\end{array}$ & $\begin{array}{l}\text { t- } \\
\text { value }\end{array}$ & $\begin{array}{l}\text { - } \\
\text { value }\end{array}$ & Remarks \\
\hline & Associate Professor & 90 & \multirow[b]{2}{*}{178} & 97.49 & 8.235 & 0.868 & \multirow[b]{2}{*}{2.807} & \multirow[b]{2}{*}{.006} & \multirow{2}{*}{$\begin{array}{l}\text { Significant } \\
(p>0.05 \text { level })\end{array}$} \\
\hline & Assistant Professor & 90 & & 94.34 & 6.717 & 0.708 & & & \\
\hline
\end{tabular}

There is no significant difference with regard to self-esteem score between Associate and Assistant Professor of college is rejected at 0.05 level of significance as t-value (2.807) is greater than critical value (1.98). Therefore, it can be concluded that there is a significant difference with regard to self-esteem score between Associate and Assistant Professors of college $\left(\mathrm{t}_{\mathrm{obs}}=2.807>\mathrm{t}_{0.05}, 178=1.98\right)$.

$\mathrm{H}_{0}$-b: There is no significant difference with regard to self-esteem score between Associate Professor and part-time \& Guest faculty of college.

$\mathrm{H}_{0}$-b is tested by employing ' $\mathrm{t}$ ' test. The result is presented in below table.

Table-6: Showing t-test of self-esteem between Associate Professors and Part-time \& Guest faculty of college

\begin{tabular}{|c|c|c|c|c|c|c|c|c|c|}
\hline \multirow[t]{3}{*}{$\begin{array}{l}\text { Self-esteem } \\
\text { Score }\end{array}$} & $\begin{array}{l}\text { Designation of } \\
\text { teachers }\end{array}$ & $\mathbf{N}$ & Df & Mean & SD & $\begin{array}{l}\text { Std. error } \\
\text { mean }\end{array}$ & $\begin{array}{l}\text { t- } \\
\text { value }\end{array}$ & $\begin{array}{l}\text { p- } \\
\text { value }\end{array}$ & Remarks \\
\hline & Associate Professor & 90 & \multirow[b]{2}{*}{178} & 97.49 & 8.235 & 0.868 & \multirow[b]{2}{*}{7.415} & \multirow[b]{2}{*}{.000} & \multirow{2}{*}{$\begin{array}{l}\text { Significant } \\
(p>0.05 \text { level })\end{array}$} \\
\hline & Part-time \& Guest & 90 & & 88.26 & 8.470 & 0.892 & & & \\
\hline
\end{tabular}

There is no significant difference with regard to self-esteem score between Associate Professor and Part-time \& Guest teacher of college is rejected at 0.05 level of significance as t-value (7.415) is greater than critical value (1.98). Therefore, it can be concluded that there is a significant difference with regard to selfesteem score between Associate Professors and Part- time \& Guest teachers of college $\left(\mathrm{t}_{\mathrm{obs}}=7.415>\mathrm{t}_{0.05}\right.$, $178=1.98)$.

$\mathrm{H}_{0}$-c: There is no significant difference with regard to self-esteem score between Assistant Professor and part-time \& Guest faculty of college.

$\mathrm{H}_{0}-\mathrm{c}$ is tested by employing ' $\mathrm{t}$ ' test. The result is presented in below table.

Table-7: Showing t-test of self-esteem between Assistant Professors and Part-time \& Guest faculty of college

\begin{tabular}{|c|c|c|c|c|c|c|c|c|c|}
\hline \multirow[t]{3}{*}{$\begin{array}{l}\text { Self-esteem } \\
\text { Score }\end{array}$} & $\begin{array}{l}\text { Designation of } \\
\text { teachers }\end{array}$ & $\mathbf{N}$ & Df & Mean & SD & $\begin{array}{l}\text { Std. error } \\
\text { mean }\end{array}$ & $\begin{array}{l}\text { t- } \\
\text { value }\end{array}$ & $\begin{array}{l}\text { p- } \\
\text { value }\end{array}$ & Remarks \\
\hline & Assistant Professor & 90 & \multirow[b]{2}{*}{178} & 94.34 & 6.717 & 0.708 & \multirow[b]{2}{*}{5.343} & \multirow[b]{2}{*}{.000} & \multirow{2}{*}{$\begin{array}{l}\text { Significant } \\
(p>0.05 \text { level })\end{array}$} \\
\hline & Part-time \& Guest & 90 & & 88.26 & 8.470 & 0.892 & & & \\
\hline
\end{tabular}

There is no significant difference with regard to self-esteem score between Assistant Professor and Part-time \& Guest teacher of college is rejected at 0.05 level of significance as t-value (5.343) is greater than critical value (1.98). Therefore, it can be concluded that there is a significant difference with regard to selfesteem score between Assistant Professors and Parttime \& Guest teachers of college $\left(\mathrm{t}_{\mathrm{obs}}=5.343>\mathrm{t}_{0.05}\right.$, $178=1.98)$.

\section{RESEARCH FINDINGS}

- Self-esteem level: It is observed that $51.11 \%$ of Associate Professor, 33.33\% Assistant Professor and $15.56 \%$ part-timer and guest faculty are extremely high Self-esteem. 47.78 \% Associate Prof., $64.45 \%$ Assistant Prof. and 70\% Part-timer and guest are normal self-esteem. While $1.11 \%$ Associate prof, $2.22 \%$ Assistant Prof. and $14.44 \%$ part-timer and guest are low self-esteem.

- The study found that there is a significant difference with regard to self-esteem score among designation-wise (Associate Professor, Assistant
Professor and Part-time and guest faculty) college teachers.

- The present showed that there is a significant difference with regard to self-esteem score between Associate and Assistant Professors of college. Therefore, it can be safely concluded based on the sample that Associate Professors are more selfesteem on their job than Assistant Professors of college.

- The research found that there is a significant difference with regard to self-esteem score between Associate Professors and Part-time \& Guest teachers of college. Therefore, it can be said that Associate Professors are more self-esteem on their job than Part-time \& Guest teachers of college.

- The study found that there is a significant difference with regard to self-esteem score between Assistant Professors and Part-time \& Guest teachers of college. Therefore, it can be said that Assistant Professors are more self-esteem on their job than Part-time \& Guest teachers of college. 


\section{CONCLUSION}

From findings of the present study it can be concluded that there is a significant difference with regard to self-esteem score among designation-wise (Associate Professor, Assistant Professor and Part-time and guest faculty) college teachers. The Study also concluded that Associate Professors are more selfesteem on college than Assistant Professors and Parttime \& Guest teachers. Besides, Assistant Professor are more self-esteem on college than Part-time \& Guest teachers.

Self-esteem is eminent for teachers so that they may be proceeding in their profession with confidence, attachment, devotion and without any fear of failure [13]. But the college heads need to take care of factors affecting on teachers' self-esteem.

\section{Limitations of the study}

The study was limited to Undergraduate (B. A/B. Sc/B. Com) Degree College (except principal or teacher-in-charge) teachers affiliated to University of Calcutta, West Bengal.

\section{REFERENCES}

1. Dhar, S. \& Dhar, U. (2015). Manual for self-esteem scale. National Psychological Corporation. Agra, India.

2. James, W. (1890). The Principles of Psychology. Cambridge, MA: Harvard University Press.

3. Rosenberg, M. (1965). Society and the adolescent self-image. Princeton, NJ: Princeton University Press.

4. Blascovich, J. and Tomaka, J. (1991). Measures of Self-esteem. In J. P. Robinson, P. R. Shaver, \& L. R. Wrightsman (Eds), Measures of Personality and Social Psychological Attitudes. Academic Press, New York, 1.

5. Garry, W. (1991). Counselling to enhance selfesteem. Eric Digest. Retrieved from https://files.eric.ed.gov/fulltext/ED328827.pdf.

6. Payne, H. J. (2007). The role of organisation-based self-esteem in employee dissent expression. Communication Research reports, 24(3), 235-240.

7. Pierce, J. L. Gardner, D. G., Cummings, L. L., \& Dunham, R. B. (1993). Moderation by Organization-based self-esteem of role condition- employee response relationships. Academy of Management Journal, 36(2), 271-288.

8. Chan, S. C., Huang, X., Snape, E., \& Lam, C. K. (2013). The Janus face of Paternalistic leaders: Authoritarianism, benevolence, Subordinates' organisationG based SelfG esteem, and Performance. Journal of Organizational Behaviour, 34(1), 108-128.

9. Pierce, J. L., Gardner, D. G., Cummings, L. L., \& Dunham, R. B. (1989). Organization-based selfesteem: Construct definition, measurement, and validation. Academy of Management Journal, 32(3), 622-648.

10. Diener, E., \& Diener, M. (2009). Cross-Cultural Correlates of Life Satisfaction and Self-esteem. Culture and Well-being, 71-91. Doi:10.1007/97890-481-2352-0_4

11. Sahu, S., Srivastava, A. \& Pathardikar, D. (2019). Self-esteem and Work engagement influencing Job Satisfaction. The Indian Journal of Commerce, 72(2).

12. Jan, F., Khan, I., Khan, S., Khan, R. M., Saif, N. (2015). The factors affecting teachers' self-esteem in the higher educational institutions. Research on Humanities and Social Sciences, 5(9), 132-135.

13. Tabassum, F., \& Ali, A. M. (2012). Professional self-esteem of secondary school teachers. Asian Social Science, 8(2), 206-210.

14. Vigneshvaran, K., Divya, M. A., Krishna, V. K., \& Sinu, E. (2017). Self-esteem and Emotional Intelligence Among College teachers. Journal of Mental Health Education, 1(1).

15. Shah, K., \& Pathak, S. (2014). Perceived selfesteem among secondary and higher secondary school teachers. The International Journal of Indian Psychology, 2(1).

16. Dey, K. B., Rahman, A., \& Akther, Y. (2013). Teacher's self-esteem and job satisfaction: Pilot study in Chittagong Region. The Chittagong University. J of Biological Science, 8(1\&2), 99105.

17. Zafar, N., Mubashir, T., Tariq, S., Kazmi, S. M. F., Zaman, H., \& Zahid, A. (2014). Self-esteem and job satisfaction in male and female teachers in Public and private schools. Pakistan Journal of Social \& Clinical Psychology, 12(1), 46-50.

18. Cevik, B. G. (2017). The roles of life satisfaction, teaching efficacy and self-esteem in predicting teachers' job satisfaction. Universal Journal of Educational Research, 5(3).

Cite This Article: Dipankar Das \& Md. Kutubuddin Halder (2021). Comparison the Self-Esteem among Different Designated Teachers of Undergraduate College. East African Scholars J Edu Humanit Lit, 4(4), 190-195. 